\title{
Analisis Model Pengukuran Tinggi Permukaan Air Dengan Metode Canny Edge Detection dan Image Contouring Sebagai Indikator Peringatan Dini Bencana Banjir
}

\author{
Frederick Alexander ${ }^{1}$, Imelda $^{2}$ \\ ${ }^{1,2}$ Department of Master Computer Science, Universitas Budi Luhur, Indonesia
}

\begin{tabular}{l} 
Article Info \\
\hline Article history: \\
Received Apr 14, 2021 \\
Revised Agus 1, 2021 \\
Accepted Sep 06, 2021 \\
\hline
\end{tabular}

\section{Keywords:}

Flood

IP CCTV

Edge detection

Contour

Rectangle bounding

\begin{abstract}
Flood disaster remains a natural phenomenon that often occurs in Indonesia, especially in the Wisma Tajur Housing Complex area, Tangerang City which causes property losses including the safety of the souls of the affected community. The difficulty experienced so far is how to measure the water level to obtain alert status information as an indicator of flood warning. As a solution in overcoming these problems, this research proposes a method based on digital image processing with canny edge detection algorithms and image contouring to measure river water levels. Canny edge detection and image contouring were chosen due to their accuracy in detecting the edges of the image and the ease of the computation process. The steps taken in this research are to conduct a simulation experiment of measuring the water level using a water container that can describe the situation in the river, then doing field testing. Canny edge detection produces an outline that can then be detected by the contour, then water level measurements can be made on the bounding rectangle that is formed and changes dynamically with fluctuations in water level. The contribution of this research is the use of black measuring lines that are processed using thresholding techniques to facilitate the process of measuring water level using a combination of canny edge detection and image contouring techniques as well as adding attributes/features using threshold, MinVal, and MaxVal values on the canny edge. Sampling testing produces an accuracy of $99.96 \%$, prototype testing produces $100 \%$ accuracy, and direct testing produces an accuracy of $99.85 \%$.
\end{abstract}

Copyright $\odot 2021$ Universitas Indraprasta PGRI. All rights reserved.

\section{Corresponding Author:}

Frederick Alexander,

Department of Master Computer Science,

Universitas Budi Luhur,

Jl. Ciledug Raya, Petukangan Utara, Jakarta Selatan, 12260. DKI Jakarta

Email: frederick.alexander.n@gmail.com

\section{PENDAHULUAN}

Banjir masih menjadi bencana rutin dan bahkan di beberapa daerah di Indonesia menjadi bencana berskala besar. Bencana tersebut menjadi keresahan bagi masyarakat yang tinggal di daerah dengan tinggi permukaan tanah yang rendah serta yang berada di sekitaran perlintasan aliran sungai pada umumnya. Sistem drainase yang buruk serta intensitas hujan yang meningkat pada musim penghujan juga seringkali menjadi faktor meningkatnya potensi bencana banjir [1].

Berdasarkan data dari BNPB yang dapat dilihat pada Gambar 1, dalam rentang waktu 5 tahun terakhir yaitu 2016 - 2020 bencana banjir masih mendominasi sebagai bencana terbanyak. Tercatat sebanyak 1.271 kejadian bencana merupakan banjir dari jumlah total 9.376 kejadian bencana yang terjadi pada tahun 2019, kemudian pada tahun 2020 tercatat sebanyak 635 kejadian bencana merupakan banjir dari jumlah total sebanyak 2.271 kejadian bencana yang terjadi pada tahun 2020. Hal tersebut menunjukkan bahwa bencana 
banjir masih menjadi peringkat pertama dari bencana alam lainnya yang sudah dan berpotensi akan berdampak lagi bagi masyarakat.

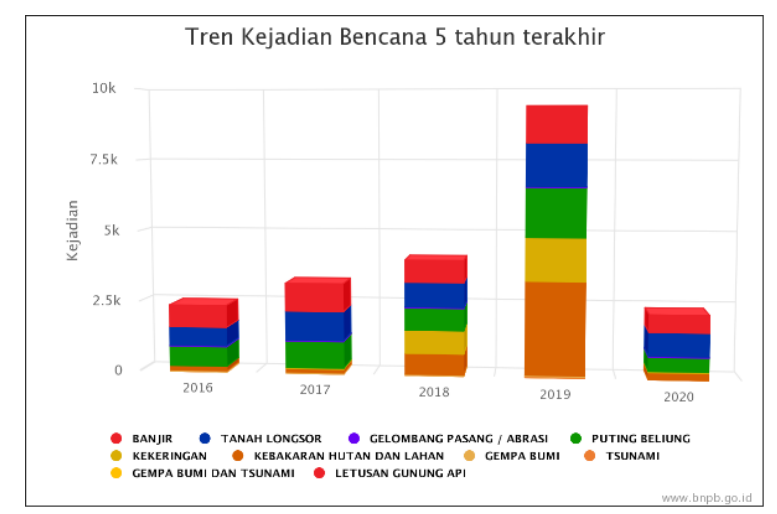

Gambar 1 : Tren Kejadian Bencana Tahun 2016-2020

Sumber : (BNPB, 2020)

Dalam ketentuan umum Pasal 1 Undang-undang Nomor 24 Tahun 2007 tentang penanggulangan bencana sebagai berikut:

"Bencana adalah peristiwa atau rangkaian peristiwa yang mengancam dan mengganggu kehidupan dan penghidupan masyarakat yang disebabkan, baik oleh faktor alam dan atau faktor non-alam maupun faktor manusia sehingga mengakibatkan timbulnya korban jiwa manusia, kerusakan lingkungan, kerugian harta benda, dan dampak psikologis".

"Bencana alam adalah bencana yang diakibatkan oleh peristiwa atau serangkaian peristiwa yang disebabkan oleh alam antara lain berupa gempa bumi, tsunami, gunung meletus, banjir, kekeringan, angin topan, dan tanah longsor" [2].

Penjelasan lebih rinci tentang bahaya adalah peristiwa alami atau buatan manusia yang mengancam akan berdampak buruk terhadap kehidupan, harta benda, atau aktivitas manusia, hingga menyebabkan bencana. Sehingga, bencana terjadi ketika bahaya dan kerentanan [3]. Curah hujan yang tinggi di musim penghujan juga menjadi kontribusi dalam peningkatan debit aliran air di sungai, khususnya dari dataran yang lebih tinggi menuju ke dataran yang rendah yang berpotensi menyebabkan banjir. Bencana banjir tidak hanya menyebabkan kerugian material yang merusak harta benda namun juga immaterial seperti trauma dan ketakutan yang berkepanjangan. Segala macam upaya pastinya telah dilakukan dalam rangka melakukan pencegahan dari bencana banjir, namun disamping itu banjir juga merupakan bencana alam yang tidak dapat dihindari [4].

Masalah yang masih sering ditemui adalah sulitnya cara mengukur ketinggian air sungai sebagai indikator untuk memprediksi kapan datangnya bencana banjir yang berpotensi melanda wilayah pemukiman, khususnya bagi daerah yang padat penduduknya. Selama ini pemantauan ketinggian air dilakukan dengan melihat langsung kondisi ketinggian air sungai. Pembacaan manual dengan mata tidak efisien tetapi juga sering bias, tidak akurat, dan status kewaspadaannya tidak pasti. Hal tersebut menyulitkan masyarakat untuk melakukan evakuasi barang berharga terlebih lagi keselamatan jiwa [5].

Dampak positif yang harus diberikan oleh sebuah sistem peringatan dini adalah memberikan peringatan tepat waktu dan mempersiapkan respon yang efektif terhadap potensi terjadinya bencana. Kemajuan teknologi komputer saat ini memberikan terobosan untuk membuat sebuah sistem peringatan dini yang dibuat dari alat sederhana dengan biaya yang rendah. Sistem peringatan dini harus dapat berfungsi secara terus menerus dalam memberikan peringatan dan informasi deteksi ketinggian air sungai [6].

Penelitian sebelumnya terkait pengukuran ketinggian permukaan air diantaranya menggunakan pelacakan ketinggian air berdasarkan warna dengan background image substraction dilakukan dengan menggunakan kamera IP yang merekam video yang kemudian dianalisis menggunakan aplikasi matlab dengan berdasarkan sudut, posisi ketinggian, dan intensitas cahaya [7]. Topik yang menjadi masalah penelitian adalah prediksi banjir yang akan melanda pemukiman. Untuk itu diperlukan sebuah sistem yang dapat memberikan informasi terkini bagi masyarakat sebagai acuan dalam pemantauan perubahan tinggi permukaan air sungai di sekitar wilayah pemukiman dengan tujuan meningkatkan kewaspadaan akan bahaya bencana banjir sehingga 
berdampak . Dengan sistem pemantauan ini, masyarakat dapat mempersiapkan diri dalam mengamankan harta benda hingga proses evakuasi ke tempat yang lebih aman dapat dilakukan segera [8].

Objek penelitian adalah sungai di wilayah Komplek Perumahan Wisma Tajur yang berlokasi di Kelurahan Tajur, Kecamatan Ciledug dengan koordinat yang bersumber dari Google Earth GPS 6¹4'16.88', S, $106^{\circ} 41^{\prime 2} 20.13$ ' E. Tercatat Komplek Perumahan Wisma Tajur beberapa kali pernah mengalami bencana banjir, yaitu pada Tahun 2007, 2009, 2012, 2014, dan 2020. Penelitian dilakukan dengan melakukan pengujian pada prototipe sebagai simulasi kenaikan tinggi permukaan air, yang kemudian nilai akurasinya akan dibandingakan dengan pengujian lapangan yaitu di sungai.

Menurut publikasi dari Badan Pusat Statistik Kota Tangerang pada Tahun 2018, jumlah penduduk di Kecamatan Ciledug adalah sebanyak 198.448 jiwa, dengan jumlah penduduk terbanyak di Kelurahan Tajur sebanyak 19.054 jiwa yang terdiri dari 9.629 laki-laki, 9.425 perempuan dengan kepadatan penduduk 14.219 penduduk/Km2. Padatnya jumlah penduduk didukung dengan banyaknya pemukiman seperti kompleks perumahan, real estate, dan perkampungan sekitarnya. Hampir semua pemukiman yang berada di wilayah Kelurahan Tajur dilintasi oleh sungai [9]. Kontribusi dari penelitian ini adalah penggunaan garis ukur berwarna hitam yang diproses menggunakan teknik thresholding sehingga memudahkan proses pengukuran ketinggian air menggunakan kombinasi teknik canny edge detection dan image contouring.

\subsection{Pengolahan Citra Digital}

Pengolahan citra digital dapat diartikan sebagai ilmu memodifikasi citra digital melalui pemrosesan komputer digital. Karena baik gambar maupun komputer yang memproses citra bersifat digital. Perubahan yang terjadi pada gambar biasanya dilakukan secara otomatis dan mengandalkan algoritma yang dirancang. Hal ini sangat bertolak belakang dengan skenario pemrosesan lain, seperti menyentuh foto menggunakan alat airbrush di perangkat lunak pengedit foto, di mana gambar diproses secara manual dan keberhasilan tugas bergantung pada kemampuan manusia itu sendiri sebagai operator [10]. Pengolahan citra digital pada penelitian ini menggunakan OpenCV yang dilengkapi lebih dari 2500 pustaka algoritma yang dioptimalkan [11] yang dipadukan dengan bahasa pemrograman python dimana berdasarkan survei pada tahun 2018 oleh JetBrains sebuah perusahaan pengembang perangkat lunak yaitu sebanyak $84 \%$ pengembang menggunakan python sebagai bahasa pemrograman mereka [12].

\subsection{Canny Edge}

Canny edge detection adalah algoritma deteksi tepi populer yang dikembangkan oleh John F. Canny pada tahun 1986 dan merupakan algoritma detektor tepi multi-tahap [13]. Deteksi tepi adalah salah satu fitur paling mendasar dalam pemrosesan gambar. Detektor tepi yang ideal harus dapat mendeteksi tepi dalam berbagai kondisi dan pada saat yang sama mampu mengurangi kebisingan (noise) dan memberikan lokalisasi tepi yang baik. Hal tersebut cukup sulit untuk dilakukan karena selalu ada tantangan antara menyimpan informasi dan mengurangi kebisingan secara bersamaan.

Deteksi tepi adalah salah satu fitur paling mendasar dalam pemrosesan gambar. Detektor tepi yang ideal harus dapat mendeteksi tepi dalam berbagai kondisi dan pada saat yang sama mampu mengurangi kebisingan (noise) dan memberikan lokalisasi tepi yang baik. Hal tersebut cukup sulit untuk dilakukan karena selalu ada tantangan antara menyimpan informasi dan mengurangi kebisingan secara bersamaan [14].

\section{METODE}

\subsection{Metode Penelitian}

Metode penelitian yang digunakan pada penelitian ini adalah metode eksperimen. Penelitian dilakukan dengan melakukan percobaan pemantauan pengukuran ketinggian air dengan mendeteksi perubahan ketinggian pixel pada rectangle bounding box yang terbentuk dari kumpulan contour yang dideteksi setelah proses canny edge detection pada garis ukur / referensi di bagian dinding sungai. Pemantauan ketinggian air kemudian akan dibagi menjadi 5 klasifikasi status berdasarkan perbedaan jarak pixel yang terdeteksi, yaitu normal, siaga 3, siaga 2, siaga 1, dan waspada. Tingkat kewaspadaan ditunjukkan dengan jarak pixel pada rectangle bounding box yang semakin kecil.

Dengan melakukan pelacakan contour pada garis hasil proses canny edge detection, diharapkan pemantauan ketinggian air dapat diukur dengan akurat dan dapat memberikan manfaat berupa informasi potensi kenaikan tinggi permukaan air ungai bagi warga disekitar supaya waspada terhadap potensi bencana banjir. Hipotesis penelitian ini adalah diduga akurasi pengukuran ketinggian air dapat mencapai lebih dari $96 \%$ dengan menggunakan kombinasi teknik canny edge detection dan image contouring.

\subsection{Metode Pemilihan Sampel}


Data sampel diambil dengan melakukan eksperimen dan simulasi pemantauan perubahan ketinggian air di dalam wadah / container seperti ditunjukkan pada Gambar 2.

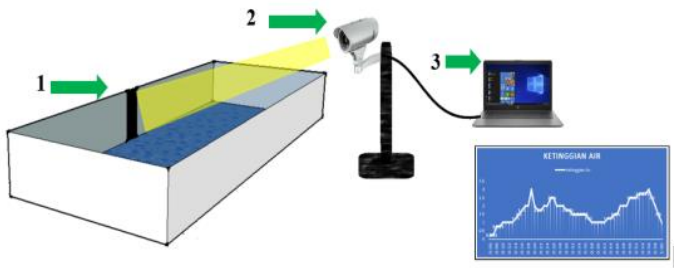

Gambar 2 : Sistem Perancangan Pengukuran

Kamera CCTV IP yang akan ditempatkan pada bagian sisi wadah air yang memiliki kemampuan dalam melakukan perekaman gambar garis ukur baik pada saat intensitas cahaya yang baik (siang hari), maupun saat penurunan intensitas cahaya (malam hari). Kamera digunakan untuk proses pengambilan gambar, dimana kamera tersebut terhubung langsung dengan laptop. Proses selanjutnya, dengan menggunakan kode program yang dibuat untuk melakukan pemantauan pengukuran dengan aplikasi OpenCV berbasis bahasa pemrograman python yang sudah terpasang di laptop, proses pemantauan dan pengambilan gambar dilakukan untuk melihat hasil ketinggian air di dalam wadah berdasarkan tinggi rectangle bounding yang terbentuk dari hasil canny edge detection dan contouring.

Penulis melakukan simulasi menggunakan wadah air dengan alasan kemudahan untuk melihat secara langsung dan cepat perubahan ketinggian airnya dengan melakukan penambahan/pengurangan volume air, dimana jika dibandingkan dengan melakukan percobaan secara langsung di sungai perlu menunggu untuk melihat perubahan ketinggian airnya. Periode pengambilan data gambar dilakukan selama 66 menit dengan target yang dicapai sejumlah 2.000 gambar untuk setiap klasifikasi status, sehingga total seluruhnya terdapat 10.000 gambar untuk 5 klasifikasi status (Normal, Siaga 3, Siaga 2, Siaga 1, Waspada).

Dengan menggunakan bantuan perangkat lunak Microsoft Excel, maka penulis melakukan tabulasi perhitungan rata-rata dari jumlah 2.000 gambar yang didapatkan dari masing-masing klasifikasi status seperti ditunjukkan pada Gambar 3.

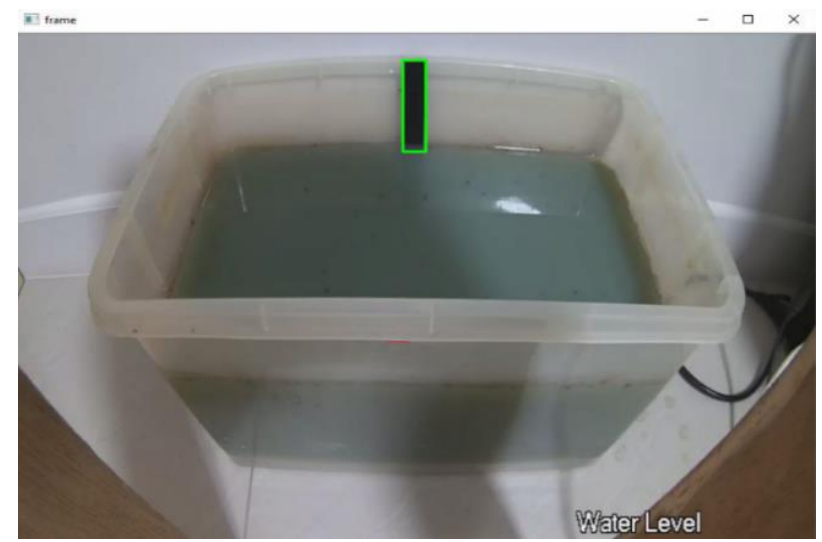

Gambar 3 : Prototipe Pengukuran Ketinggian Air

\subsection{Rancangan Sistem}

Pada tahap ini dilakukan perancangan sistem secara keseluruhan berdasarkan analisa kebutuhan dari identifikasi permasalahan yang ada, tahap ini meliputi pembuatan desain serta pemodelan dari algoritma yang diusulkan terhadap sistem yang diperlukan untuk membuat prototipe atau sistem pengukuran ketinggian air berbasis pengolahan citra digital. 


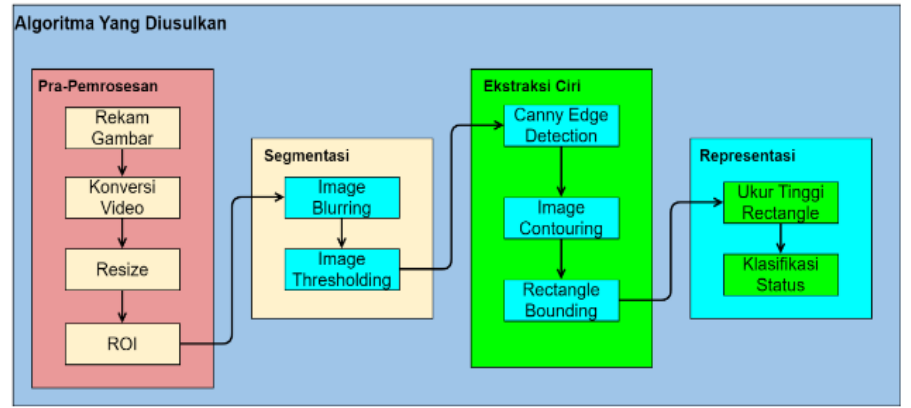

Gambar 4 : Algoritma Yang Diusulkan

Berdasarkan Gambar 4, terdapat 4 bagan utama dalam melakukan pengolahan citra, yaitu prapemrosesan, segmentasi, ekstraksi ciri, dan representasi. Algoritma yang diusulkan disajikan ke dalam bentuk tabel yang terlihat pada Tabel 1, kemudian lebih lanjut akan dijelaskan lebih rinci mengenai algoritma yang diusulkan dan metode eksperimen yang dilakukan pada penelitian ini.

Tabel 1. Algoritma Yang Diusulkan

\begin{tabular}{cl}
\hline No & \multicolumn{1}{c}{ Langkah } \\
\hline 1. & Rekam gambar menggunakan kamera CCTV IP \\
\hline 2. & Resize gambar ke ukuran 800 x 600 pixel \\
\hline 3. & Tentukan Region of Interest \\
\hline 4. & Image Blurring \\
\hline 5. & Image Thresholding \\
\hline 6. & Canny Edge Detection \\
\hline 7. & Image Contouring berdasarkan canny edge yang terdeteksi \\
\hline 8. & Rectangle Bounding pada area contour \\
\hline 9. & Ukur tinggi rectangle bounding \\
\hline 10. & Klasifikasi status ketinggian air didapatkan \\
\hline
\end{tabular}

\section{HASIL DAN PEMBAHASAN}

\subsection{Pengujian Sampling}

Simulasi pengukuran ketinggian air dilakukan dengan mengukur jarak permukaan garis ukur yang masih terlihat dan tidak terendam air. Setelah tinggi rectangle bounding didapatkan, maka 5 jenis klasifikasi ketinggian air dapat ditentukan, yaitu normal, siaga 3, siaga 2, siaga 1, dan waspada seperti yang ditunjukkan hasil ROI pada Gambar 5.

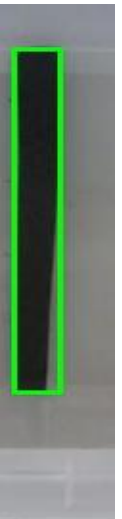

(a)

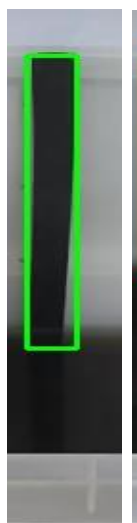

(b)

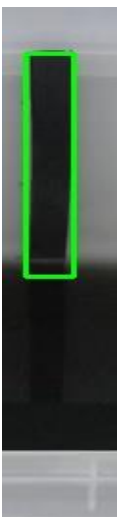

(c)

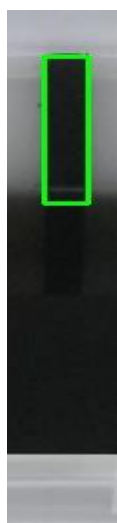

(d)

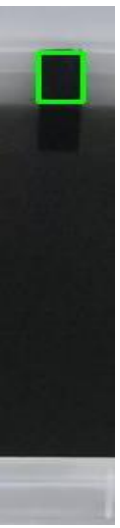

(e)

(a) Normal, (b) Siaga 3, (c) Siaga 2, (d) Siaga 1, (e) Waspada

\section{Pengujian Sampling 1}

Pengujian sampling 1 dilakukan pada tanggal 15 Desember 2020 Pukul 14:00 WIB dilakukan pada wadah yang diisi air dengan jarak kamera dan garis ukur sejauh $30 \mathrm{~cm}$. Ketinggian air pada status normal 
hingga waspada sebanyak masing-masing 2000 frame per klasifikasi status berhasil diukur. Grafik hasil pengukuran ditunjukkan pada Gambar 6.

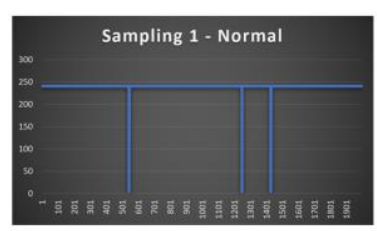

(a)

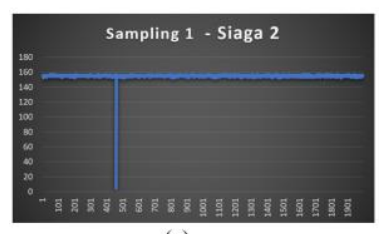

(c)

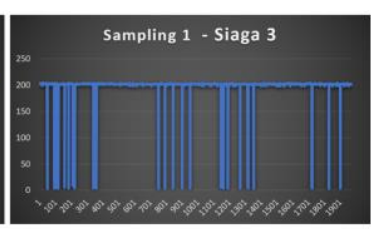

(b)

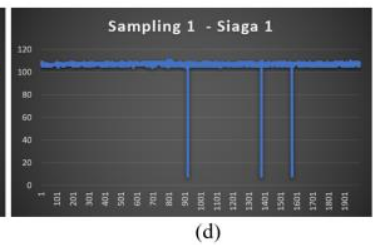

(d)

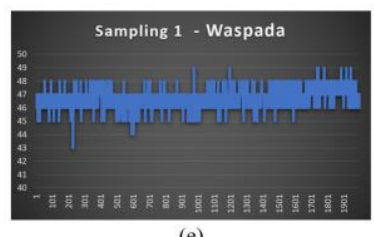

(e)

Gambar 6 : Grafik Pengujian Sampling 1

(a) Normal, (b) Siaga 3, (c) Siaga 2, (d) Siaga 1, (e) Waspada

Tabel 2 menunjukkan akurasi pengujian 1 sampling. Total data sebanyak 10.000 frame. Data yang benar sebanyak 9.968 frame, sedangkan data yang salah sebanyak 32 frame. Akurasi rata-rata dari 5 klasifikasi status adalah sebesar $99.68 \%$

Tabel 2 : Rangkuman Hasil Pengujian Sampling 1

\begin{tabular}{lcccc}
\hline \multicolumn{1}{c}{ Status } & Frame Benar & Frame Salah & Total Frame & Akurasi \\
\hline Normal & 1.997 & 3 & 2.000 & $99,85 \%$ \\
\hline Siaga 3 & 1.975 & 25 & 2.000 & $98,75 \%$ \\
\hline Siaga 2 & 1.999 & 1 & 2.000 & $99,95 \%$ \\
\hline Siaga 1 & 1.997 & 3 & 2.000 & $99,85 \%$ \\
\hline Waspada & 2.000 & 0 & 2.000 & $100 \%$ \\
\hline & & & Akurasi Rata - Rata & $99,68 \%$ \\
\hline
\end{tabular}

\section{Pengujian Sampling 2}

Pengujian sampling 2 dilakukan pada tanggal 20 Januari 2021 Pukul 14:00 WIB dilakukan pada wadah yang diisi air dengan jarak kamera dan garis ukur sejauh $100 \mathrm{~cm}$. Ketinggian air pada status normal hingga waspada sebanyak masing-masing 2000 frame per klasifikasi status berhasil diukur. Grafik hasil pengukuran ditunjukkan pada Gambar 7. 


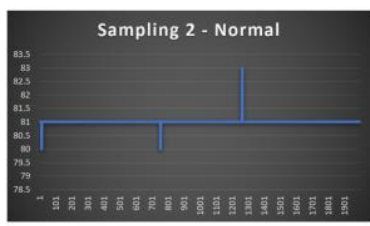

(a)

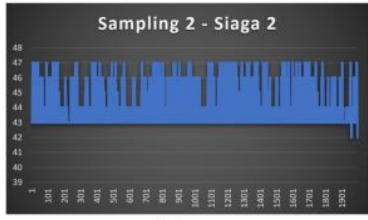

(c)

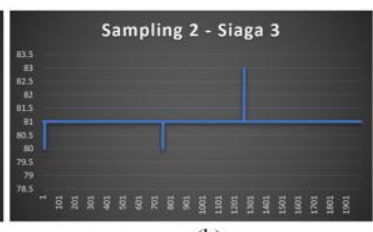

(b)

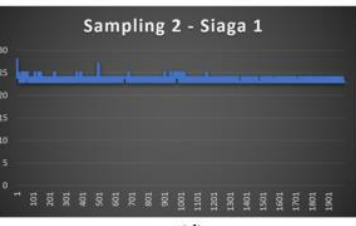

(d)

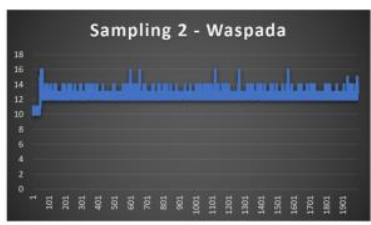

Gambar 7 : Grafik Pengujian Sampling 2

(a) Normal, (b) Siaga 3, (c) Siaga 2, (d) Siaga 1, (e) Waspada

Tabel 3 menunjukkan akurasi pengujian 2 sampling. Total data sebanyak 10.000 frame. Data yang benar sebanyak 9.996 frame, sedangkan data yang salah sebanyak 4 frame. Akurasi rata-rata dari 5 klasifikasi status adalah sebesar $99.96 \%$.

Tabel 3 : Rangkuman Hasil Pengujian Sampling 2

\begin{tabular}{lcccc}
\hline \multicolumn{1}{c}{ Status } & Frame Benar & Frame Salah & Total Frame & Akurasi \\
\hline Normal & 2.000 & 0 & 2.000 & $100 \%$ \\
\hline Siaga 3 & 1.996 & 4 & 2.000 & $99,8 \%$ \\
\hline Siaga 2 & 2.000 & 0 & 2.000 & $100 \%$ \\
\hline Siaga 1 & 2.000 & 0 & 2.000 & $100 \%$ \\
\hline Waspada & 2.000 & 0 & 2.000 & $100 \%$ \\
\hline & & Akurasi Rata - Rata & $99,96 \%$ \\
\hline
\end{tabular}

\section{Pengujian Sampling 3}

Pengujian sampling 3 dilakukan pada tanggal 21 Januari 2021 Pukul 14:00 WIB dilakukan pada wadah yang diisi air dengan jarak kamera dan garis ukur sejauh $50 \mathrm{~cm}$. Ketinggian air pada status normal hingga waspada sebanyak masing-masing 2000 frame per klasifikasi status berhasil diukur. Grafik hasil pengukuran ditunjukkan pada Gambar 8. 


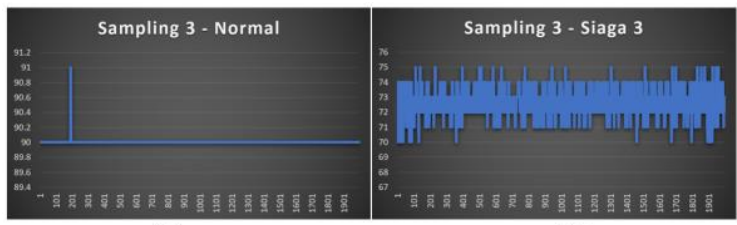

(a)

(b)

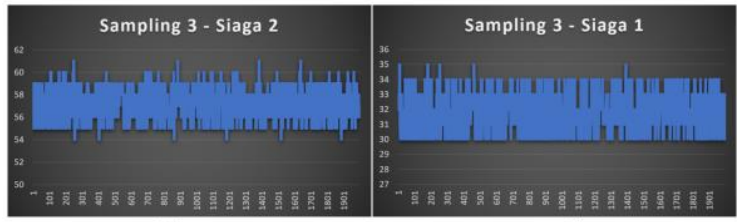

(c)

(d)

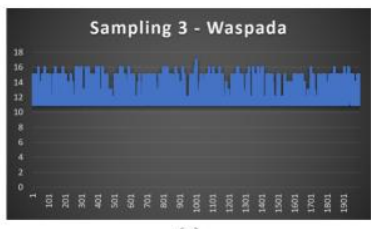

Gambar 8 : Grafik Pengujian Sampling 3

(a) Normal, (b) Siaga 3, (c) Siaga 2, (d) Siaga 1, (e) Waspada

Tabel 4 menunjukkan akurasi pengujian 3 sampling. Total data sebanyak 10.000 frame. Data yang benar sebanyak 9.933 frame, sedangkan data yang salah sebanyak 67 frame. Akurasi rata-rata dari 5 klasifikasi status adalah sebesar $99.31 \%$.

Tabel 4 : Rangkuman Hasil Pengujian Sampling 3

\begin{tabular}{lcccc}
\hline \multicolumn{1}{c}{ Status } & Frame Benar & Frame Salah & Total Frame & Akurasi \\
\hline Normal & 2.000 & 0 & 2.000 & $100 \%$ \\
\hline Siaga 3 & 2.000 & 0 & 2.000 & $100 \%$ \\
\hline Siaga 2 & 1.994 & 4 & 2.000 & $99,7 \%$ \\
\hline Siaga 1 & 2.000 & 0 & 2.000 & $100 \%$ \\
\hline Waspada & 1.937 & 63 & Akurasi Rata - Rata & $99,31 \%$ \\
\hline
\end{tabular}

\subsection{Pengujian Prototipe}

\section{Pengujian Prototipe 1}

Pengujian pengukuran dilakukan dengan menjalankan program yang akan merekam gambar menggunakan kamera pada masing-masing level ketinggian air dengan total sebanyak 5 klasifikasi status dengan pemantauan pada wadah yang diisi air sesuai dengan klasifikasi statusnya. Proses pengujian dilakukan pada tanggal 15 Desember 2020 Pukul 13:00 WIB dilakukan dengan menambahkan volume air dengan ukuran acak secara manual dan bertahap menggunakan gelas ukur ke dalam wadah sebanyak 10x untuk setiap klasifikasi status ketinggian, sehingga didapatkan sebanyak 42 frame.

Hasil pengujian menggunakan metode pengolahan citra digital dengan teknik canny edge detection dan image contouring didapatkan bahwa sistem dapat melakukan pemantauan ketinggian air dengan hasil $100 \%$ dari total 42 pengujian yang dilakukan. Semakin besar tingkat keberhasilan pengujian, maka semakin akurat sistem dalam memberikan data terkait peringatan potensi bencana banjir. Grafik hasil pengukuran dapat dilihat pada Gambar 8 . 


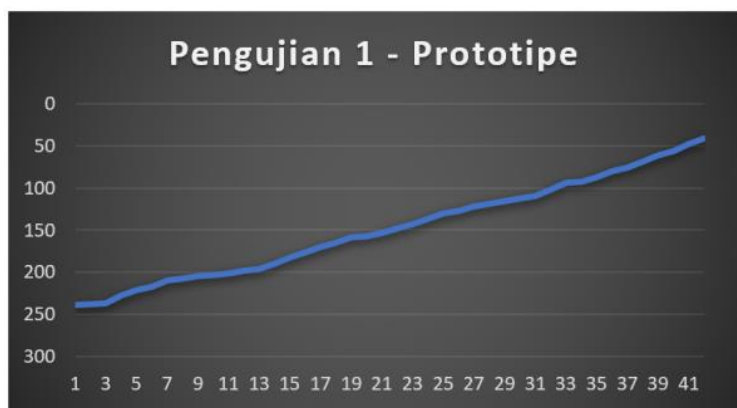

Gambar 9 : Grafik Pengujian 1 - Prototipe

Tabel 5 menunjukkan akurasi pengujian 1 prototipe. Total data sebanyak 42 frame. Data yang benar sebanyak 42 frame. Akurasi yang didapatkan berdasarkan persamaan 3.2 adalah sebesar 100\%.

Tabel 5 : Rangkuman Hasil Pengujian Prototipe 1

\begin{tabular}{ccc}
\hline \multicolumn{3}{c}{ Pengujian 1 - Prototipe } \\
\hline $\mathrm{n}=42$ & Benar & Salah \\
\hline Jumlah Citra & 42 & 0 \\
\hline
\end{tabular}

$$
\operatorname{Akurasi}(\%)=\frac{42}{42} X 100 \%=100 \%
$$

\section{Pengujian Prototipe 2}

Pengujian kedua dilakukan dengan simulasi menambahkan volume air di dalam wadah menggunakan pompa yang diaktifkan menggunakan mikro kontroller Arduino untuk melihat perubahan ketinggian air secara realtime. Proses pengujian dilakukan pada tanggal 26 Januari 2021 Pukul 13:00 WIB. Pengujian ini bertujuan untuk menguji akurasi pengukuran ketinggian air dimulai dari status normal hingga waspada.

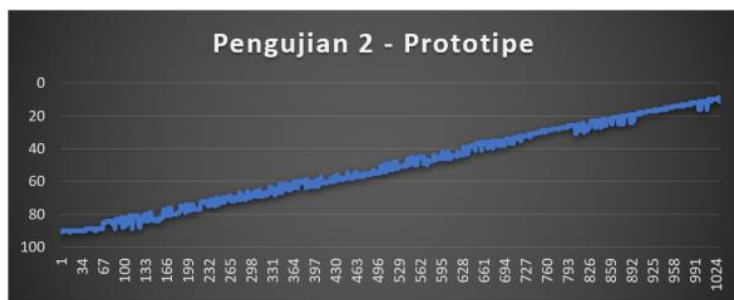

Gambar 10 : Grafik Pengujian 2 - Prototipe

Pengujian berlangsung selama 18 menit yang menghasilkan 1030 frame relevan antara tinggi rectangle bounding dengan klasifikasi status ketinggian air. Sehingga, terlihat pada Gambar 10 grafik hasil pengujian yang menunjukkan ketinggian air berangsur naik dari level normal sampai dengan waspada. Tabel 6 merupakan hasil yang menunjukkan akurasi sebesar $100 \%$.

Tabel 6 : Rangkuman Hasil Pengujian Sampling

\begin{tabular}{ccc}
\hline \multicolumn{3}{c}{ Pengujian 2 - Prototipe } \\
\hline $\mathrm{n}=1.030$ & Benar & Salah \\
\hline Jumlah Citra & 1.030 & 0 \\
\hline
\end{tabular}

$$
\operatorname{Akurasi}(\%)=\frac{1.030}{1.030} X 100 \%=100 \%
$$

\section{Pengujian Prototipe 3}

Pengujian ketiga dilakukan dengan simulasi noise pada wadah dan kamera untuk menguji apakah sistem dapat melakukan pengukuran saat terjadi hujan atau cuaca ekstrim. Simulasi dilakukan dengan menyemprotkan air pada wadah dan kamera sebagai external noise, serta mengaduk air di dalam wadah untuk membuat riak air. 
Hujan merupakan salah satu sumber gangguan dalam pemrosesan pengolahan citra digital yang dapat mempengaruhi hasil pengukuran sistem pengukuran ketinggian air. Pengujian dilakukan pada tanggal 02 Maret 2021 Pukul 13:00 WIB. Pengujian berlangsung selama 10 menit yang menghasilkan 1.683 frame relevan antara tinggi rectangle bounding dengan klasifikasi status ketinggian air. Sehingga, terlihat pada Gambar 11.

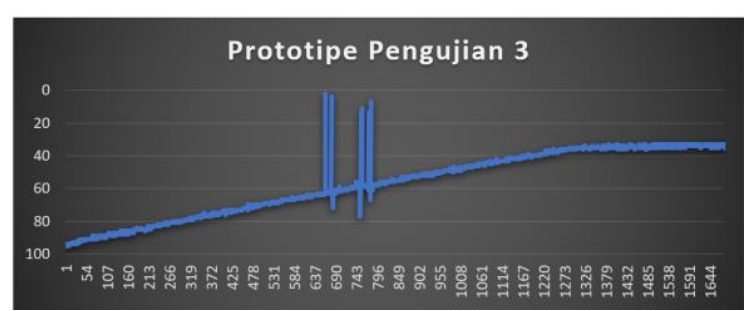

Gambar 11 : Grafik Pengujian 1 - Lapangan

Tabel 7 menunjukkan akurasi pengujian 3 prototipe. Total data sebanyak 1.683 frame. Data yang benar sebanyak 1.674 frame. Akurasi yang didapatkan berdasarkan persamaan 3.2 adalah sebesar 99,46\%.

Tabel 7 : Rangkuman Hasil Pengujian Sampling

\begin{tabular}{|ccc|}
\hline \multicolumn{3}{|c|}{ Pengujian 3 - Prototipe } \\
\hline $\mathrm{n}=1.683$ & Benar & Salah \\
\hline Jumlah Citra & 1.674 & 0 \\
\hline
\end{tabular}

$\operatorname{Akurasi}(\%)=\frac{1.674}{1.683} X 100 \%=99,46 \%$

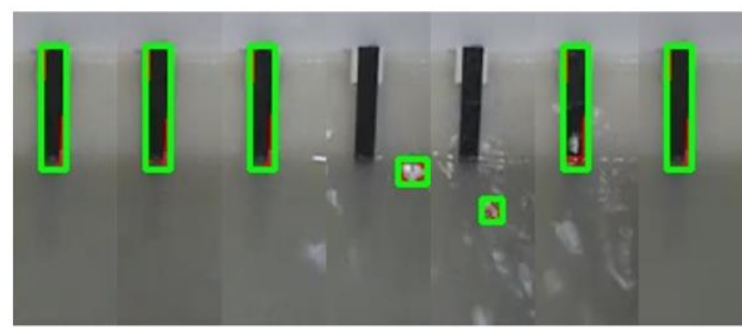

Gambar 12 : Simulasi Noise Prototipe

Sesuai hasil frame pada Gambar 12, terbukti bahwa simulasi percikan air pada wadah dan kamera tidak mempengaruhi pengukuran. Namun, riak air yang mempengaruhi pengukuran dimana rectangle bounding terbentuk pada area yang salah. Kesalahan tersebut terjadi hanya dalam waktu yang sangat singkat, kemudian pengukuran kembali normal. Pengaturan nilai thresholding dibawah 127 akan mempengaruhi pembacaan dan akhirnya menyebabkan contour error.

\subsection{Pengujian Lapangan}

\section{Pengujian Lapangan 1}

Penelitian di lokasi obyek penelitian dilakukan pada tanggal 17 Januari 2021 Pukul 14:00 dengan menempatkan garis ukur pada jarak 5 meter antara dinding sungai seperti terlihat pada Gambar 13. Kamera diletakkan di sisi seberang dengan mengarah ke garis ukur setinggi 2 meter. 


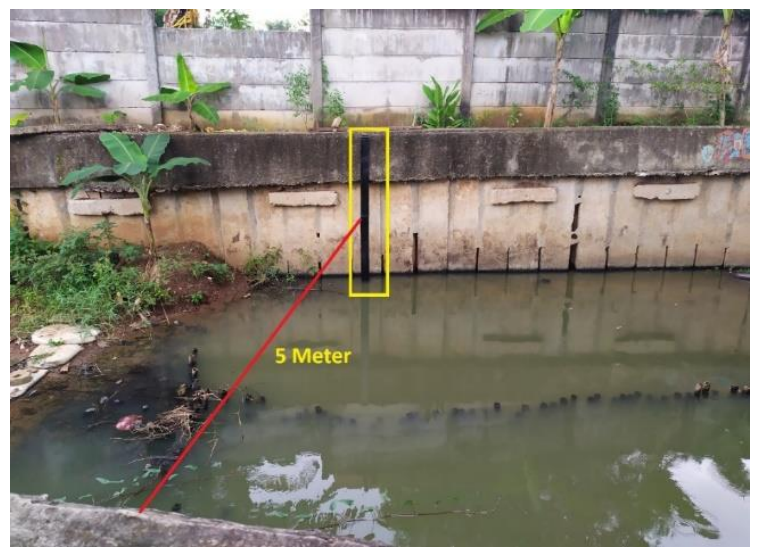

Gambar 13 : Situasi Obyek Penelitian Sungai

Pengujian di sungai dilakukan dengan merekam sebanyak 2000 frame selama 33 menit. Pengujian yang dimaksud untuk mengukur akurasi pengukuran pada 1 status ketinggian air tertentu saja (dalam hal ini status ketinggian air normal) karena perubahan ketinggian air tidak terjadi secara realtime. Hasil percobaan yang dilakukan dapat dilihat pada Tabel 8.

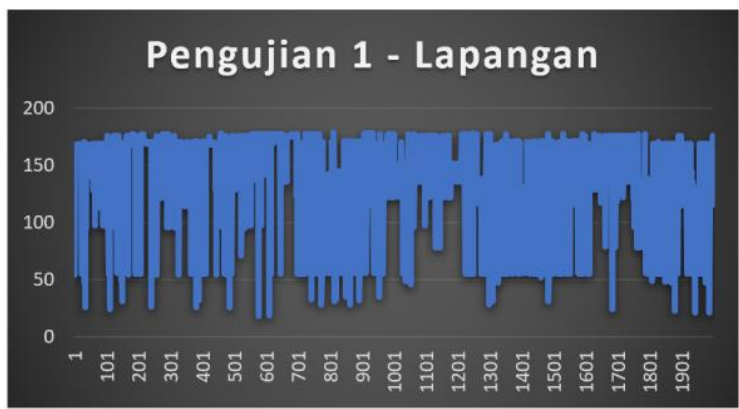

Gambar 14 : Grafik Pengujian 1 - Lapangan

Berdasarkan Gambar 14, dari total 2.000 frame yang dihasilkan, 1.131 frame benar dan 869 frame lainnya salah, cuplikan data pengukuran dapat dilihat pada Tabel 4.15. Sesuai dengan pengujian, maka masih terdapat kesalahan pembacaan yang kemudian dapat dihitung nilai akurasi yang didapatkan sebesar 56,55\% sesuai dengan akurasi pada Tabel 8.

Tabel 8 : Rangkuman Hasil Pengujian Lapangan 1

\begin{tabular}{ccc}
\hline \multicolumn{3}{c}{ Pengujian 1 - Lapangan } \\
\hline $\mathrm{n}=2.000$ & Benar & Salah \\
\hline Jumlah Citra & 1.131 & 869 \\
\hline
\end{tabular}

$$
\text { Akurasi }=\frac{1.131}{2.000} \times 100 \%=56,55 \%
$$

\section{Pengujian Lapangan 2}

Pengujian kedua dilakukan pada tanggal 09 Februari 2021 Pukul 14:00 WIB karena nilai akurasi pada pengujian 1 dinilai kurang mendekati harapan. Pengujian kedua dilakukan dengan melakukan penelitian langsung di sungai seperti terlihat pada Gambar 28 dengan mengubah nilai threshold, minVal, dan maxVal dari parameter canny edge detection dan didapatkan hasil akurasi pengukuran sebesar $58.3 \%$. 


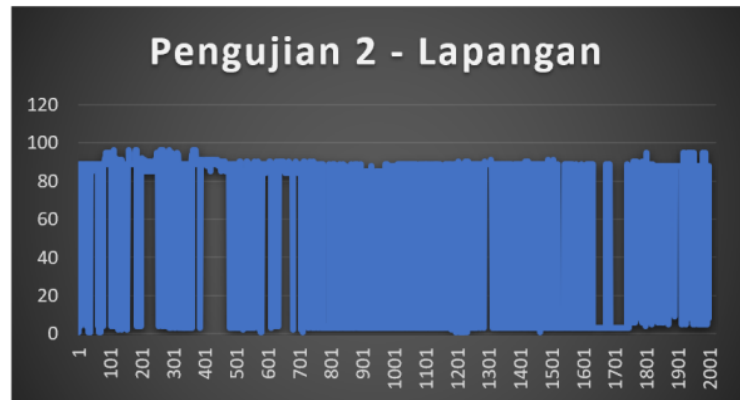

Gambar 15 : Grafik Pengujian 2 - Lapangan

Sesuai dengan Gambar 15 pengujian dilakukan dengan status ketinggian air normal yang dilakukan selama 33 menit dan menghasilkan 2.000 frame yang terdiri dari 1.166 frame dengan hasil benar dan 834 frame dengan hasil salah, sehingga akurasi yang didapatkan dijelaskan sesuai dengan Tabel 9.

Tabel 9 : Rangkuman Hasil Pengujian Lapangan 2

\begin{tabular}{ccc}
\hline \multicolumn{3}{c}{ Pengujian 2 - Lapangan } \\
\hline $\mathrm{n}=1.166$ & Benar & Salah \\
\hline Jumlah Citra & 1.166 & 834 \\
\hline
\end{tabular}

\section{Pengujian Lapangan 3}

$$
\text { Akurasi }=\frac{1.166}{2.000} \times 100 \%=58,3 \%
$$

Pengujian ketiga dilakukan pada tanggal 10 Februari 2021 Pukul 14:00 WIB karena nilai akurasi pada pengujian 2 dinilai masih menghasilkan akurasi dibawah 90\%. Pengujian ketiga dilakukan di sungai seperti terlihat pada Gambar 16 dengan megatur nilai threshold, minVal, dan maxVal pada parameter canny edge detection dan dilakukan pengujian ulang ke obyek yaitu sungai dengan jarak kamera dan garis ukur yang sama dengan pengujian sebelumnya.

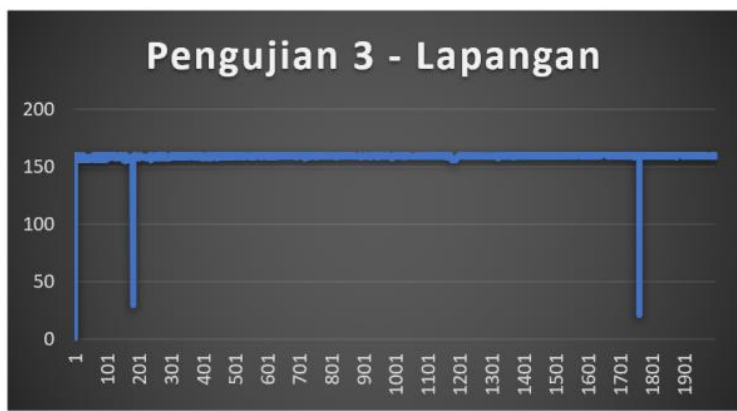

Gambar 16 : Grafik Pengujian 3 - Lapangan

Sesuai dengan Gambar 16 pengujian dilakukan dengan status ketinggian air normal yang dilakukan selama 33 menit dan menghasilkan 2.000 frame yang terdiri dari 1.997 frame dengan hasil benar dan 3 frame dengan hasi salah, sehingga akurasi yang didapatkan dijelaskan sesuai dengan Tabel 10.

Tabel 10 : Rangkuman Hasil Pengujian Lapangan

\begin{tabular}{ccc}
\hline \multicolumn{3}{c}{ Pengujian 3 - Lapangan } \\
\hline $\mathrm{n}=2.000$ & Benar & Salah \\
\hline Jumlah Citra & 1.997 & 3 \\
\hline
\end{tabular}

$$
\text { Akurasi }=\frac{1.997}{2.000} \times 100 \%=99,85 \%
$$

Untuk melakukan pengukuran ketinggian air dilakukan pengujian sampling, pengujian prototipe, dan pengujian lapangan. Tabel 11 menunjukkan hasil pengujian sampling dengan akurasi tertinggi sebesar $99.96 \%$. Tabel 12 menunjukkan hasil pengujian prototipe dengan hasil akurasi tertinggi sebesar 100\%. Tabel 13 menunjukkan hasil pengujian lapangan dengan hasil akurasi tertinggi sebesar $99.85 \%$. 


\subsection{Pembahasan}

Dari serangkaian proses yang dilakukan, maka hasil pengujian sangat memuaskan dengan akurasi lebih dari harapan yaitu diatas $96 \%$. dimana penelitian ini bertujuan untuk mengukur ketinggian air sungai sebagai peringatan bencana banjir berdasarkan beberapa tingkat kewaspadaan.

Tabel 11 : Rangkuman Hasil Pengujian Sampling

\begin{tabular}{|c|c|c|c|c|}
\hline Pengujian & Tanggal & Jarak & Obyek & Akurasi \\
\hline Pengujian 1 & 15 Dec 2020 & $30 \mathrm{~cm}$ & Wadah & $99,68 \%$ \\
\hline Pengujian 2 & 20 Jan 2021 & $100 \mathrm{~cm}$ & Wadah & $99,96 \%$ \\
\hline Pengujian 3 & 21 Jan 2021 & $50 \mathrm{~cm}$ & Wadah & $99,31 \%$ \\
\hline
\end{tabular}

Tabel 12 : Rangkuman Hasil Pengujian Prototipe

\begin{tabular}{|c|c|c|c|c|}
\hline Pengujian & Tanggal & Jarak & Obyek & Akurasi \\
\hline Pengujian 1 & 15 Jan 2021 & $50 \mathrm{~cm}$ & Wadah & $100 \%$ \\
\hline Pengujian 2 & 26 Jan 2021 & $50 \mathrm{~cm}$ & Wadah & $100 \%$ \\
\hline Pengujian 3 & 02 Mar 2021 & $50 \mathrm{~cm}$ & Wadah & $99,46 \%$ \\
\hline
\end{tabular}

Tabel 13 : Rangkuman Hasil Pengujian Lapangan

\begin{tabular}{|c|c|c|c|c|}
\hline Pengujian & Tanggal & Jarak & Obyek & Akurasi \\
\hline Pengujian 1 & 17 Jan 2021 & $500 \mathrm{~cm}$ & Sungai & $56,55 \%$ \\
\hline Pengujian 2 & 08 Feb 2021 & $500 \mathrm{~cm}$ & Sungai & $58 \%$ \\
\hline Pengujian 3 & 09 Feb 2021 & $500 \mathrm{~cm}$ & Sungai & $99,85 \%$ \\
\hline
\end{tabular}

\section{PENUTUP}

\subsection{Kesimpulan}

Sistem pengukuran ketinggian air sungai berhasil dibuat dengan menggunakan metode pengolahan citra digital melalui pendekatan pengujian prototipe yang dilanjutkan dengan pengujian lapangan dengan teknik canny edge detection dan image contouring. Penggunaan threshold dengan garis ukur berwarna hitam memudahkan proses pengukuran ketinggian air di setiap metode pengujian. Pengujian sistem berhasil dilakukan dengan akurasi pengujian sampling sebesar $99.31 \%$, pengujian prototipe sebesar 99,46\%, dan pengujian lapangan sebesar $99.85 \%$.

\subsection{Saran}

Karena keterbatasan waktu dan kondisi dalam melakukan penelitian, Diharapkan pada penelitian selanjutnya untuk mengembangkan sistem pemantauan ketinggian air menggunakan kamera dengan fitur infra merah, sehingga pengukuran di malam hari dapat dilakukan. Algoritma deteksi tepi lainnya seperti ShenCastan dapat digunakan untuk menghasilkan deteksi tepi yang lebih detail. Future research akan dilakukan dengan membuat sistem pemantauan ketinggian air berbasis web sebagai peringatan dini yang bertujuan memberikan informasi secara real time kepada warga berpotensi terdampak banjir.

\section{DAFTAR PUSTAKA}

[1] I. Riyanto, "Image Processing-based Flood Detection for Online Flood Early Warning System," IJJSS 2014 6th Indones. Japan Jt. Sci. Symp., 2014.

[2] U. 24 T. 2007, "Undang-Undang Republik Indonesia Nomor 24 Tahun 2007 Tentang Penanggulangan Bencana," vol. 67, no. 6, pp. 14-21, 2007.

[3] WHO, "Disasters and Emergency Definitions," WHO/EHA Train. Packag., no. March, pp. 1-26, 2002.

[4] I. Riyanto et al., "Web Camera Sensor Coupled With Lidar Data Flood Map For Flood Warning System,” IGARSS 2019 - 2019 IEEE Int. Geosci. Remote Sens. Symp., pp. 9406-9408, 2019.

[5] Y. T. Lin, Y. C. Lin, and J. Y. Han, "Automatic Water Level Detection Using Single Camera Images with Varied Poses," Meas. J. Int. Meas. Confed., vol. 127, no. May, pp. 167-174, 2018.

[6] W. H. Wan Hassan, A. Z. Jidin, S. A. C. Aziz, and N. Rahim, "Flood Disaster Indicator of Water Level Monitoring System," Int. J. Electr. Comput. Eng., vol. 9, no. 3, pp. 1694-1699, 2019.

[7] S. S. K. Adhadi Kurniawan, I Wayan Mustika, "Pelacakan Level Ketinggian Air Berdasarkan Warna dengan Background Substraction,” no. February, pp. 6-8, 2015.

[8] R. Avanzato, F. Beritelli, A. Cavallaro, M. Cuccia, and T. Lombardo, "A River Flood Monitoring Technique Based On Image Splitting Algorithms,” Proc. 2019 10th IEEE Int. Conf. Intell. Data Acquis. Adv. Comput. Syst. Technol. Appl. IDAACS 2019, vol. 1, pp. 507-511, 2019. 
[9] Badan Pusat Statistik Kota Tangerang, Kecamatan Ciledug Dalam Angka 2019. BPS Kota Tangerang, 2019.

[10] O. Marques, Practical Image and Video Processing Using MATLAB®. John Wiley \& Sons, Inc., Hoboken, New Jersey., 2011.

[11] A. Mordvintsev, "Introduction to OpenCV-Python Tutorials," 2013.

[12] J. Foundation, "Python Developers Survey 2018 Results," 2018.

[13] J. Canny, "A Computational Approach to Edge Detection," IEEE Trans. Pattern Anal. Mach. Intell., vol. PAMI-8, no. 6, pp. 679-698, 1986.

[14] A. M. Muad and A. Hussain, "Robust Edge Detection Based On Canny Algorithm For Noisy Images," J. Theor. Appl. Inf. Technol., vol. 95, no. December, pp. 5104-5114, 2017. 